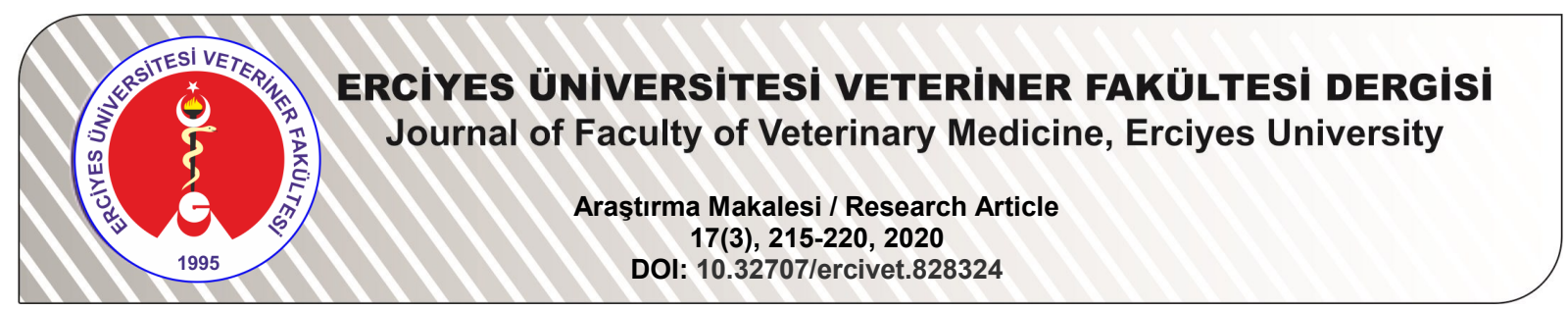

\title{
Kadmiyum Uygulanan Farelerde Oluşturulan Oksidatif Strese Karşı Resveratrolün Koruyucu Etkisinin Araştırılması*
}

\author{
Canan IŞIK BİRCAN ${ }^{1}$, Oğuz MERHAN² \\ ${ }^{1}$ Kafkas Üniversitesi, Sağlık Bilimleri Enstitüsü, Biyokimya Anabilim Dalı, Kars-TÜRKIYE \\ ${ }^{2}$ Kafkas Üniversitesi, Veteriner Fakültesi, Biyokimya Anabilim Dalı, Kars-TÜRKIYYE
}

Sorumlu yazar: Oğuz MERHAN; E-posta: oguzmerhan@hotmail.com; ORCID: 0000-0002-3399-0667

Atıf Yapmak İçin: Isık Bircan C, Merhan O. Kadmiyum uygulanan farelerde oluşturulan oksidatif strese karşı resveratrolün koruyucu etkisinin araştırılması. Erciyes Univ Vet Fak Derg 2020; 17(3): 215-220.

Özet: Kadmiyum ve diğer ağır metaller hem çevresel hem de mesleki maruziyetlerle insan sağlığını tehdit etmekte ve sanayide yaygın olarak kullanılmaktadır. Resveratrol anti-inflamatuvar, antioksidan, antitümör ve immunomodulatör özellikleri olan doğal bir polifenolik bileşiktir. Bu nedenle yapılan çalışmada farelerin plazma, karaciğer, böbrek ve kalp dokusunda kadmiyum toksisitesine karşı resveratrolün koruyucu etkisi araştırımıştır. Çalışmada 35 fare eşit olarak 5 gruba ayrılmıştır. Kontrol grubu, alkol grubu, kadmiyum grubu $\left(\mathrm{CdCl}_{2}, 1 \mathrm{mg} / \mathrm{kg} / \mathrm{gün}\right)$, resveratrol grubu (10 mg/kg/gün), kadmiyum+resveratrol grubu (1 mg/kg/gün+10 mg/kg/gün) olarak belirlenmiştir. Tüm uygulamalar 21 gün süreyle oral gavaj yoluyla uygulanmıştır. Uygulama süresi sonunda karaciğer, böbrek ve kalp dokusunda oksidatif stresin göstergesi olarak malondialdehit (MDA) ve nitrik oksit (NO) miktarları, antioksidan savunmanın biyobelirteci olarak redükte glutatyon (GSH) miktarı, akut faz yanıtın bir göstergesi olan total siyalik asit (TSA) ve plazmada aspartat aminotransferaz (AST), alanin aminotransferaz (ALT), gamma glutamil transpeptidaz (GGT) aktiviteleri spektrofotometrik yöntemlerle belirlenmiştir. Kontrole göre, kadmiyum verilen grupta doku (karaciğer, böbrek ve kalp) MDA, NO, TSA düzeyleri ile plazma AST, ALT, GGT aktiviteleri önemli derecede artarken, doku GSH düzeyi ise önemli derecede azalmıştır. Kadmiyum+resveratrol verilen grupta ise doku MDA, NO, TSA düzeyleri ile plazma AST, ALT, GGT aktivitelerinin kadmiyum verilen gruba göre istatistiksel olarak önemli derecede azalırken, doku GSH düzeyi ise önemli derecede artmıştır. Sonuç olarak kadmiyumun toksik etkisine karşı resveratrolün karaciğer, böbrek ve kalpte koruyucu etkisinin olabileceği kanısına varılmıştır.

Anahtar kelimeler: Kadmiyum, oksidatif stres, resveratrol, siyalik asit

The Investigation of the Protective Effect of Resveratrol on Oxidative Stress Levels in Mice Given Cadmium Summary: Cadmium and other heavy metals which are commonly used in industry could threaten human health with both environmental and occupational exposures. Resveratrol, a natural polyphenol, is thought to have some properties such as anti-inflammatory, antioxidant, antitumor and immunomodulatory. Therefore, the present study was designed to examine the protective effect of resveratrol on cadmium toxicity in plasma, liver, kidney and heart tissue of mice. In our study, thirty five mice were equally divided into five groups. Control group, alcohol group, cadmium group $\left(\mathrm{CdCl}_{2}, 1\right.$ $\mathrm{mg} / \mathrm{kg} / \mathrm{day})$, resveratrol group (10 mg/kg/day), cadmium+resveratrol group $(1 \mathrm{mg} / \mathrm{kg} / \mathrm{day}+10 \mathrm{mg} / \mathrm{kg} / \mathrm{day})$. All treatments were administered orally via gavage for 21 days. The amount of malondialdehyde (MDA) and nitric oxide (NO) as an indicator of oxidative stress in liver, kidney, and heart tissue at the end of the application period, the amount of reduced glutathione (GSH) as a biomarker of antioxidant defense, total sialic acid (TSA) as an indicator of acute phase response and aspartate aminotransferase (AST), alanine aminotransferase (ALT), gamma glutamyl transpeptidase (GGT) activities in plasma were determined by spectrophotometric methods. In cadmium group, it was determined that tissue MDA, NO, TSA level and plasma AST, ALT, GGT activities increased significantly compared to control in the tissue (liver, kidney, and heart), while tissue GSH level decreased significantly compared to control. In cadmium+resveratrol group, it was determined that tissue MDA, NO, TSA level and plasma AST, ALT, GGT activities decreased, while tissue GSH level increased statistically significantly compared to cadmium groups. As a result, it was concluded that resveratrol may have a protective effect on the liver, kidney and heart against the toxic effect of cadmium.

Key words: Cadmium, oxidative stress, resveratrol, sialic acid

\section{Giriş}

Yer kabuğunun doğal bir elementi olan kadmiyum madencilik ve endüstriyel faaliyetler esnasında çevre-

$\begin{array}{ll}\text { Geliş Tarihi/Submission Date } & : 17.03 .2020 \\ \text { Kabul Tarihi/Accepted Date } & : 20.07 .2020\end{array}$

*Bu çalışma ilk isimli araştırıcının Yüksek Lisans tezinden özetlenmiş olup Kafkas Üniversitesi Bilimsel Araştırma Projeleri Birimi tarafından 2016-TS-33 kodlu proje ile desteklenmiştir. ye yüksek emisyon düzeyinde yayıldığından insan sağlığını tehdit eden önemli bir çevresel kirletici olarak değerlendirilmektedir. Kadmiyumun insanlarda çeşitli organ kayıpları ve kanseri tetiklediği bilinmektedir. Kadmiyumun büyük bir kısmı karaciğer ve böbreklerde birikmektedir (Kim ve ark., 2013). Birikime bağlı olarak oluşan doku hasarları ve hücre ölümlerinin sistemik enflamasyon ve reaktif oksijen türlerinin 
üretimi ile indüklenen oksidatif stresle ilişkili olabileceği bildirilmektedir. Yapılan çalışmalarda kadmiyum kaynaklı reaktif oksijen türleri üretiminin hem zaman hem de konsantrasyona bağlı olduğu aynı zamanda süperoksit dismutaz (SOD), glutatyon peroksidaz (GPx) ve katalaz (CAT) gibi enzimlerin yanı sıra antioksidan savunmada önemli rolü olan glutatyon miktarının azalmasını da etkilediği belirtilmiştir (El-Ebiary ve ark., 2016).

Resveratrol kırmızı meyvelerde bulunan doğal polifenolik bir bileşiktir. Resveratrolün antioksidan, antiproliferatif ve anti-inflamator özelliklerinin yanı sıra kardiovasküler hastalıklar, yaşlanma, metabolik hastalıklar ve kansere karşı koruyucu etkileri bilinmektedir. Resveratrolün en iyi bilinen özelliği reaktif oksijen türleri gibi serbest radikalleri reaktif olmayan bileşiklere dönüştüren antioksidan özelliğidir (Yousef ve ark., 2017).

Nitrik oksit (NO), nitrik oksit sentazlar (NOS)'ın Larjinini okside ederek L-sitrullin oluşturmasıyla sentezlenmektedir. Memelilerin, damar endoteli, beyin, makrofaj, üriner sistem gibi farklı dokularından nöronal (nNOS), uyarılabilir (iNOS) ve endoteliyal (eNOS) olmak üzere üç farklı tip NOS izoformu izole edilmiştir. Nitrik oksit, oksidatif stres altında apoptozisi, sitotoksisiteyi, mutajenezisi ve DNA hasarını artırır, ayrıca lipit oksidasyonuna da neden olur (Atakişi ve Merhan, 2017).

Glikoproteinler, glikolipidler, polisakkaritler ve mukoproteinlerin yapısına katılan siyalik asit, mannozamin ve piruvatın kondenzasyonu ile oluşan nöraminik asitin asetillenmiş türevleridir. Total siyalik asit ise serbest, proteine ve lipide bağlı siyalik asidin toplamı$\mathrm{n}$ ifade etmektedir (Merhan ve Özcan, 2004).

Çalışmada resveratrolün, toksik bir madde olan kadmiyumun meydana getirdiği zararlı etkilerine karşı karaciğer, böbrek ve kalpte olası koruyucu etkilerinin araştırılması amaçlanmıştır.

\section{Gereç ve Yöntem}

Bu çalışma, Kafkas Üniversitesi Hayvan Deneyleri Yerel Etik Kurulu (KAÜ-HADYEK) Başkanlığının 2016/030 kodlu etik kurul onayı ile yapılmıştır. Çalışmada kullanılan Swiss albino fareler $(n=35)$ Erzurum Veteriner Kontrol Enstitüsü Deney Hayvanları Biriminden temin edilmiştir. Fareler, bir aylık adaptasyon süresi boyunca ad libitum standart fare yemi ve su ile beslenmiştir. Fareler ağırlıklarına göre her bir grupta 7 adet olmak üzere toplam 5 gruba ayrılmıştır. Kontrol grubu; ad libitum beslenen $(n=7)$, alkol grubu; \% 1'lik etil alkol (resveratrol etil alkolde çözüldüğü için) $(\mathrm{n}=7)$, kadmiyum grubu; $1 \mathrm{mg} / \mathrm{kg} / \mathrm{gün}$ kadmiyum $\left(\mathrm{CdCl}_{2}\right)(\mathrm{n}=7)$, resveratrol grubu; $10 \mathrm{mg} / \mathrm{kg} /$ gün resveratrol $(\mathrm{n}=7)$, kadmiyum+resveratrol grubu; $1 \mathrm{mg} / \mathrm{kg} /$ gün kadmiyum $\left(\mathrm{CdCl}_{2}\right)$ ve $10 \mathrm{mg} / \mathrm{kg} /$ gün resveratrol verilen gruplar olarak belirlenmiştir. Tüm uygulamalar
21 gün süreyle oral gavaj yoluyla uygulanmıştır. ÇaIışmada kullanılmak için gerekli olan kan ve doku (karaciğer, böbrek ve kalp) numuneleri alınmıştır. Son uygulamalardan 24 saat sonra, kan örnekleri antikuagülanlı (EDTA) tüplere intrakardiyak olarak alınmış ve farelere servikal dislokasyon yöntemi uygulanmıştır. Kan örnekleri, 3000 devirde 15 dakika santrifüj edilerek plazmaları elde edilmiş ve örnekler analiz edilinceye kadar $-20^{\circ} \mathrm{C}$ 'de derin dondurucuda saklanmıştır. Plazmada AST, ALT, GGT enzim aktiviteleri analizleri ticari test kitleri (Biolabo, Fransa) ile yapıımıştır. Karaciğer, böbrek, kalp dokuları hızlı ve hasarsız bir şekilde çıkarılmıştır. Biyokimyasal analiz için alınan $1 \mathrm{~g}$ karaciğer, böbrek ve kalp doku örnekleri fosfat tampon çözeltisi ile 5 kat sulandırılarak buz üzerinde, 12000 rpm'de 2 dakika boyunca homojenize edilmiştir. Homojenatlar, 14000 rpm'de $4{ }^{\circ} \mathrm{C}$ 'de 10 dakika santrifüj edilmiştir. Elde edilen süpernatantlar biyokimyasal analizler yapılana kadar $-45^{\circ} \mathrm{C}$ 'de saklanmıştır. Elde edilen süpernatantlardan MDA Yoshioka ve ark. (1979), NO Miranda ve ark. (2001), GSH Beutler ve ark. (1963), TSA analizi ise Sydow'un (1985) bildirdikleri metoda göre yapılmıştır.

\section{Istatiksel analiz}

Verilerin istatistiksel analizi SPSS ${ }^{\circledR}$ paket programı (SPSS 16.0, Chicago, IL, ABD) kullanılarak yapıldı. Gruplardaki denek sayısının azlığı tek yönlü varyans analiz varsayımını yerine getirmediğinden dolayı grupların istatistiksel karşılaştırımasında KruskalWallis sıralamalı tek-yönlü varyans analizi kullanıldı. Post-hoc çoklu karşılaştırma yöntemi olarak MannWhitney $U$ testi uygulandı. Elde edilen sonuçlar ortalama \pm standart hatası olarak verildi. İstatistiksel değerlendirmede $\mathrm{P}<0.05$ değeri istatistiksel olarak anlamlı kabul edildi.

\section{Bulgular}

Karaciğer dokusu için; kadmiyum verilen grupta kontrole göre, MDA $(P=0.001)$, NO ve TSA $(P<0.001)$ düzeylerinin arttığı, GSH ( $P=0.001)$ düzeyinin ise istatistiksel olarak azaldığı tespit edilmiştir. Kadmiyum+resveratrol verilen grupta ise kadmiyumun MDA ve GSH konsantrasyonlarına yapmış olduğu olumsuz etkiyi resveratrolün önlediği görülmüştür. Ayrıca kadmiyum+resveratrol grubunda MDA ve GSH konsantrasyonları için kontrole göre yapılan karşılaştırılmasında istatistiksel bir fark belirlenmediği $(P>0.05)$, fakat NO ve TSA konsantrasyonlarında resveratrol sayısal değer olarak kadmiyumun etkisini önlemekle beraber kontrole karşı istatistiksel olarak fark tespit edilmemiştir ( $P>0.05)$ (Tablo 1).

Böbrek dokusu için; kadmiyum verilen grupta kontrole göre, MDA, NO ve TSA düzeylerinin istatistiksel olarak arttığı $(P<0.001)$, GSH $(P=0.003)$ düzeylerinin ise azaldığı tespit edilmiştir. Kadmiyum+resveratrol verilen grupta ise kadmiyumun MDA ve GSH konsantras- 
Tablo 1. Karaciğer MDA, GSH, NO ve TSA düzeyleri

\begin{tabular}{|c|c|c|c|c|}
\hline KARACIGGER & $\begin{array}{l}\text { MDA }(\mu \mathrm{mol} / \mathrm{g} \\
\text { yaş doku) }\end{array}$ & $\begin{array}{l}\text { GSH }(\mu \mathrm{mol} / \mathrm{g} \\
\text { yaş doku) }\end{array}$ & $\begin{array}{l}\text { NO ( } \mu \mathrm{mol} / \mathrm{g} \text { yaş } \\
\text { doku) }\end{array}$ & $\begin{array}{l}\text { TSA (mg/g yaş } \\
\text { doku) }\end{array}$ \\
\hline Kontrol & $0.51 \pm 0.02^{a}$ & $3.84 \pm 0.11^{a}$ & $0.73 \pm 0.04^{a b}$ & $0.65 \pm 0.06^{a}$ \\
\hline Alkol & $0.49 \pm 0.01^{a}$ & $3.81 \pm 0.06^{a}$ & $0.67 \pm 0.04^{a}$ & $0.61 \pm 0.04^{a}$ \\
\hline Kadmiyum & $0.78 \pm 0.03^{b}$ & $2.74 \pm 0.07^{b}$ & $1.32 \pm 0.04^{c}$ & $1.47 \pm 0.05^{b}$ \\
\hline Resveratrol & $0.49 \pm 0.01^{a}$ & $3.77 \pm 0.08^{a}$ & $0.84 \pm 0.03^{b d}$ & $0.68 \pm 0.03^{a}$ \\
\hline Kadmiyum+Resveratrol & $0.56 \pm 0.02^{a}$ & $3.68 \pm 0.05^{a}$ & $0.91 \pm 0.05^{d}$ & $0.84 \pm 0.03^{c}$ \\
\hline P Değeri & 0.001 & 0.001 & $<0.001$ & $<0.001$ \\
\hline
\end{tabular}

a,b,c,d: Her sütundaki farklı harfler istatistiksel olarak önemli farkı göstermektedir.

yonlarına yapmış olduğu olumsuz etkiyi resveratrolün önlediği belirlenmiştir. Ayrıca kadmiyum+resveratrol grubunda MDA ve GSH konsantrasyonları için kontrole göre yapılan karşılaştırılmasında istatistiksel bir fark çıkmadığı $(P>0.05)$, fakat NO ve TSA konsantrasyonlarında resveratrol sayısal değer olarak kadmiyumun etkisini önlemiş gibi görünsede kontrole karşı istatistiksel olarak fark görüldüğü saptanmıştır (sırasıyla $\mathrm{P}=0.025$ ve $\mathrm{P}=0.002$ ) (Tablo 2). rak arttığı $(P<0.001)$, GSH düzeylerinin ise azaldığı $(P=0.003)$ tespit edilmiştir. Kadmiyum+resveratrol verilen grupta ise kadmiyumun MDA konsantrasyonuna yapmış olduğu olumsuz etkiyi resveratrolün önlediği saptanmıştır. Ayrıca kadmiyum+resveratrol grubunda MDA konsantrasyonu için kontrole göre yapılan karşılaştırılmasında istatistiksel bir fark olmadığı $(P>0.05)$, fakat $G S H, N O$ ve TSA konsantrasyonlarında resveratrol sayısal değer olarak kadmiyumun etki-

Tablo 2. Böbrek MDA, GSH, NO ve TSA düzeyleri

\begin{tabular}{lllll}
\hline BÖBREK & $\begin{array}{l}\text { MDA }(\mu \mathrm{mol} / \mathbf{g} \\
\text { yaş doku) }\end{array}$ & $\begin{array}{l}\text { GSH } \\
\text { yaş doku) }\end{array}$ & $\begin{array}{l}\text { NO }(\mu \mathrm{mol} / \mathbf{g} \text { yaş } \\
\text { doku) }\end{array}$ & $\begin{array}{l}\text { TSA (mg/g yaş } \\
\text { doku) }\end{array}$ \\
\hline Kontrol & $1.67 \pm 0.03^{\mathrm{a}}$ & $4.58 \pm 0.08^{\mathrm{a}}$ & $2.08 \pm 0.07^{\mathrm{a}}$ & $5.33 \pm 0.12^{\mathrm{a}}$ \\
Alkol & $1.59 \pm 0.03^{\mathrm{a}}$ & $4.61 \pm 0.05^{\mathrm{a}}$ & $2.06 \pm 0.08^{\mathrm{a}}$ & $5.28 \pm 0.05^{\mathrm{a}}$ \\
Kadmiyum $_{\text {Resveratrol }}^{2.18 \pm 0.08^{\mathrm{b}}}$ & $4.12 \pm 0.06^{\mathrm{b}}$ & $3.14 \pm 0.09^{\mathrm{b}}$ & $8.24 \pm 0.11^{\mathrm{b}}$ \\
Kadmiyum+Resveratrol $^{\mathrm{a}}$ & $1.62 \pm 0.05^{\mathrm{a}}$ & $4.53 \pm 0.07^{\mathrm{a}}$ & $2.27 \pm 0.09^{\mathrm{c}}$ & $5.62 \pm 0.07^{\mathrm{c}}$ \\
P Değeri & $1.73 \pm 0.04^{\mathrm{a}}$ & $4.47 \pm 0.07^{\mathrm{a}}$ & $2.39 \pm 0.07^{\mathrm{c}}$ & $5.97 \pm 0.09^{\mathrm{d}}$ \\
\hline
\end{tabular}

a,b,c,d: Her sütundaki farklı harfler istatistiksel olarak önemli farkı göstermektedir.

Tablo 3. Kalp MDA, GSH, NO ve TSA düzeyleri

\begin{tabular}{|c|c|c|c|c|}
\hline KALP & $\begin{array}{l}\text { MDA }(\mu \mathrm{mol} / \mathrm{g} \\
\text { yaş doku) }\end{array}$ & $\begin{array}{l}\text { GSH }(\mu \mathrm{mol} / \mathrm{g} \\
\text { yaş doku) }\end{array}$ & $\begin{array}{l}\text { NO ( } \mu \mathrm{mol} / \mathrm{g} \text { yaş } \\
\text { doku) }\end{array}$ & $\begin{array}{l}\text { TSA (mg/g yaş } \\
\text { doku) }\end{array}$ \\
\hline Kontrol & $1.09 \pm 0.03^{a}$ & $0.82 \pm 0.06^{a}$ & $1.94 \pm 0.08^{a}$ & $1.35 \pm 0.06^{\mathrm{a}}$ \\
\hline Alkol & $1.12 \pm 0.04^{\mathrm{a}}$ & $0.84 \pm 0.04^{a}$ & $1.97 \pm 0.06^{a}$ & $1.33 \pm 0.05^{a}$ \\
\hline Kadmiyum & $1.96 \pm 0.05^{b}$ & $0.56 \pm 0.04^{b}$ & $2.86 \pm 0.05^{b}$ & $2.94 \pm 0.08^{b}$ \\
\hline Resveratrol & $1.15 \pm 0.04^{\mathrm{a}}$ & $0.79 \pm 0.04^{\mathrm{ac}}$ & $2.11 \pm 0.05^{\mathrm{ac}}$ & $2.07 \pm 0.07^{c}$ \\
\hline Kadmiyum+Resveratrol & $1.27 \pm 0.06^{a}$ & $0.65 \pm 0.04^{b c}$ & $2.24 \pm 0.05^{c}$ & $2.26 \pm 0.05^{c}$ \\
\hline P Değeri & $<0.001$ & 0.003 & $<0.001$ & $<0.001$ \\
\hline
\end{tabular}

a,b,c. Her sütundaki farklı harfler istatistiksel olarak önemli farkı göstermektedir.

Tablo 4. Plazma AST, ALT ve GGT aktiviteleri

\begin{tabular}{llll}
\hline PLAZMA & AST (IU/L) & ALT (IU/L) & GGT (IU/L) \\
\hline Kontrol & $142.38 \pm 2.86^{\mathrm{ab}}$ & $53.18 \pm 3.85^{\mathrm{ab}}$ & $2.78 \pm 0.04^{\mathrm{a}}$ \\
Alkol & $144.24 \pm 6.56^{\mathrm{ab}}$ & $57.62 \pm 2.95^{\mathrm{ab}}$ & $2.82 \pm 0.07^{\mathrm{a}}$ \\
Kadmiyum & $212.78 \pm 5.13^{\mathrm{c}}$ & $105.31 \pm 3.33^{\mathrm{c}}$ & $8.63 \pm 0.38^{\mathrm{b}}$ \\
Resveratrol $_{\text {Kadmiyum+Resveratrol }}$ & $134.74 \pm 3.78^{\mathrm{a}}$ & $50.67 \pm 2.44^{\mathrm{a}}$ & $3.15 \pm 0.14^{\mathrm{a}}$ \\
P Değeri & $158.83 \pm 6.88^{\mathrm{b}}$ & $55.23 \pm 1.67^{\mathrm{b}}$ & $4.52 \pm 0.07^{\mathrm{c}}$ \\
\hline
\end{tabular}

${ }^{a, b, c}$ : Her sütundaki farklı harfler istatistiksel olarak önemli farkı göstermektedir.

Kalp dokusu için; kadmiyum verilen grupta kontrole göre, MDA, NO ve TSA düzeylerinin istatistiksel ola- sini önlemiş gibi görünsede kontrole karşı istatistiksel olarak fark belirlenmiştir (sırasıyla $\mathrm{P}=0.035, \mathrm{P}=0.025$, $\mathrm{P}=0.002$ ) (Tablo 3). 
Plazmada; kadmiyum verilen grupta kontrole göre, AST, ALT ve GGT aktivitelerinin istatistiksel olarak artış gösterdiği tespit edilmiştir (sırasıyla $\mathrm{P}<0.001$, $\mathrm{P}=0.001, \mathrm{P}<0.001)$. Kadmiyum+resveratrol verilen grupta ise kadmiyumun AST ve ALT aktivitelerine yapmış olduğu olumsuz etkiyi resveratrolün önlediği görülmüştür. Ayrıca kadmiyum+resveratrol grubunda AST ve ALT aktiviteleri için kontrole göre yapılan karşılaştırılmasında istatistiksel bir fark çıkmadığı $(P>0.05)$, GGT aktivitesinde ise resveratrolün kadmiyumun olumsuz etkisini tolere edemediği belirlenmiştir $(P=0.002)$ (Tablo 4).

\section{Tartışma ve Sonuç}

Kadmiyum ve diğer ağır metaller insan sağlığını tehdit etmektedir. Yarı ömrünün uzun olması, sanayide yaygın olarak kullanımı ve hemen hemen tüm sistemlere toksik etki gösterebilmesi sebebiyle ayrı bir öneme sahip olduğu belirtilmiştir (Wang ve Du, 2013). Pulmoner ve gastrointestinal absorbsiyonun ardından büyük bir kısmının karaciğer ve böbrekte biriktiği ve idrarla atıldığı bildirilmiştir. Karaciğerde küçük peptidler ve sülfidril grupları aracılığı ile glutatyon veya afinitesi daha yüksek olan metal bağlayıcı protein olan metallotionein gibi proteinlerle kompleksler oluştururak antioksidan sistemlerin etkinliğinin azalmasına neden olduğu saptanmıştır (Kim ve ark., 2013).

Resveratrol üzüm, kırmızı şarap gibi birçok bitki türünde bulunan ve antiinflamatuvar, antioksidan, antitümör ve immunomodulatör özellikleri olan doğal bir polifenolik bileşik olduğu bildirilmiştir. Oksidatif strese bağlı olarak oluşan hücresel hasarları ve apoptozu önleyerek süperoksit anyonlarını ve hidrojen peroksiti hücreden uzaklaştırmada oldukça güçlü bir etkiye sahip olduğu belirtilmiştir (Das ve Maulik, 2006).

Deney hayvanlarında yapılan birçok çalışmanın sonuçlarına göre akut kadmiyuma maruz kalma durumunda oksidatif stresin artarak öncelikle karaciğer hasarı ve kadmiyum toksisitesine neden olduğu bildirilmektedir (Sarkar ve ark., 1995; Bagchi ve ark., 1996). El-Demerdash ve ark. (2004) ratlarda 15 gün boyunca oral gavaj yoluyla $5 \mathrm{mg} / \mathrm{kg} \mathrm{CdCl}{ }_{2}$ uyguladıkları bir çalışmada kadmiyumun karaciğer dokusunda hücre hasarı oluşturduğunu göstermişlerdir. Yapılan farklı bir çalışmada, kadmiyum uygulaması sonucunda karaciğerde hasar oluştuğu ve karaciğer homojenatlarında MDA düzeyinin arttığı, SOD ve CAT aktivitelerinde ise düşüş saptandığı bildirilmiştir (Koyu ve ark., 2006). Nitrik oksitin ise hipertansiyon, astım, septik şoka kadar değişken bir dizi hastalıkların patogenezinde rol oynadığı, DNA hasarını arttırdığı, demirsülfür içeren enzimlerin fonksiyonunu değiştirdiği ve mitokondriyal solunumu bozduğu bildirilmektedir (Gross ve Wolin, 1995). In vitro bir çalışmada, ortamdaki kadmiyumun endotel hücreleri tarafından üretilen NO'i inhibe ettiği (Kishimoto ve ark., 1994), başka bir çalışmada ise kronik kadmiyum maruziyeti sonra- sında ratların plazma NO düzeylerini düşürdüğü gösterilmiştir (Skoczynska ve Martynowicz, 2005). Çalışmamızda ise karaciğer dokusunda kadmiyum verilen grupta kontrole göre MDA, NO ve TSA düzeyleri artarken, kadmiyum+resveratrol verilen grupta MDA seviyelerinin resveratrol aracılı olarak önlendiği fakat NO ve TSA konsantrasyonlarında istatistiksel olarak bir farkın oluşmadığı görülmüştür.

Metallotionein proteinlerinin sentezinin karaciğerde olmasından dolayı karaciğer kadmiyum toksikasyonu için önemli bir organdır (Coyle ve ark., 2000). Shiraishi ve ark. (1994) tek başına kadmiyum uygulaması sonucu karaciğer metallotionein miktarının arttığını göstermiştir. Metallotioneinlerin yanında hücresel antioksidan savunma sistemlerinin işlevselliği de bir diğer önemli husustur. Ratlarda yapılan bir çalışmada, kadmiyum uygulaması sonucunda karaciğer SOD ile CAT aktivitelerinde düşüş saptandığı bildirilmiştir (Koyu ve ark., 2006). Yaptığımız çalışmada da literatürdeki bilgilere paralel olarak kadmiyum verilen grubun karaciğer dokularında kontrole kıyasla GSH düzeylerinin azaldığı tespit edilmiş ve aynı zamanda kadmiyum+resveratrol verilen grupta GSH konsantrasyonlarının kontrol düzeyine yaklaştığı görülmüştür. Bu koruyucu etkinin, resveratrolün hücresel antioksidan savunmayı güçlendirmesi yoluyla şekillendiği kanaati oluşmuştur.

Hepatositlerde sentezlenen plazma ALT, AST ve safra kanalında sentezlenen GGT enzimleri karaciğer hasarının belirlenmesinde kullanılan önemli belirteçlerdendir (Pratt ve Kaplan, 2000). Farelerde oluşturulan deneysel toksikasyon sonucunda ise AST ve ALT aktivitesindeki yükselmeyi resveratrol uygulanmasının düşürdüğü bildirilmiştir (Sener ve ark., 2006). Elde ettiğimiz bulgularda da literatürde sunulan bilgiler ile paralel olarak plazma AST, ALT ve GGT aktivitelerinin kadmiyum verilen grupta kontrol grubuna nazaran, istatistiksel olarak arttığını göstermekle birlikte kadmiyum+resveratrol uygulamasının AST ve ALT aktivitelerini fizyolojik sınırlara çektiği görülmüştür. Ayrıca kadmiyum+resveratrol grubunda AST ve ALT aktiviteleri için kontrole karşı yapılan karşılaştırılmasında istatistiksel bir fark olmadığı tespit edilmiştir. Fakat GGT aktivitesinde resveratrol sayısal değer olarak kadmiyumun etkisini önlemiş gibi görülse de kontrole kıyasla istatistiksel bir farkın varlığı tespit edilmiştir.

Böbrekler ise kadmiyum toksikasyonunda sekonder hedef organ olarak değerlendirilmektedir. Çünkü kadmiyum boşaltım sistemi yoluyla vücuttan uzaklaştırılmaktadır. Kadmiyum proksimal tübülleri etkileyerek böbreklerde fonksiyon bozukluğuna neden olmakta bunun sonucunda da kanda yüksek asit seviyesiyle seyreden birçok hastalığın patogenezinde rol oynamaktadır (Tsuruoka ve ark., 2000). Renugadevi ve Prabu (2009) yaptıkları çalışmada 4 hafta boyunca 5 $\mathrm{mg} / \mathrm{kg} \mathrm{CdCl}_{2}$ 'ün böbrek dokusunda hasar oluşturdu- 
ğunu bildirmişlerdir. Yapılan farklı bir çalışmada da, tek başına kadmiyum uygulamasının böbrek metallotionein miktarlarında önemli bir artışa neden olduğu gösterilmiştir. Bu bilgilere ek olarak resveratrolün iskemik böbrek modelinde lipit peroksidasyon seviyesini düşürdüğü bilinmektedir (Sener ve ark., 2006). Elde ettiğimiz verilere göre böbrek dokularında, kadmiyum verilen grupta kontrole grubuna kıyasla, MDA, NO ve TSA düzeylerinin istatistiksel olarak arttığını, GSH düzeylerinin ise azaldığını göstermekte olup kadmiyum+resveratrol verilen grupta kadmiyumun MDA ve GSH konsantrasyonlarına yapmış olduğu olumsuz etkiyi resveratrolün önlediği görülmüştür. Çünkü aynı grubun MDA ve GSH konsantrasyonları için kontrole göre yapılan karşılaştırılmasında istatistiksel bir fark çıkmamıştır. Fakat NO ve TSA konsantrasyonlarında resveratrol sayısal değer olarak kadmiyumun etkisini önlemiş gibi görünse de kontrole göre istatistiksel farkın şekillendiği görülmektedir.

Kadmiyumun, kalpte metabolik ve yapısal bozuklukların yanı sıra hipertansiyon oluşumunda da etkili olduğu belirtilmektedir (Tomera ve ark., 1991). Kardiyomiyositlerde mitokondri hasarı oluşturarak hücre solunum ve enerji metabolizmasında bozulmaya neden olduğu bilinmektedir (Skowerski ve ark., 2000). Ayrıca kadmiyumun kalpte birikme oranının, karaciğer ve böbrekle kıyaslandığında oldukça düşük olduğu kaydedilmiştir (Tomera ve ark., 1991). Kadmiyum okside maruz kalan işçilerde, kardiyovasküler sistem hastalıkların görülme sıklığının 4 kat arttığı rapor edilmiştir (Vorobieva ve Eremeeva, 1980). Yapılan çalışmalar resveratrolün kalp dokusu için koruyucu etkilere sahip olduğunu işaret etmektedir (Giovannini ve ark., 2001). Ek olarak rat aorta düz kas hücre kültürlerinde yapılan farklı bir çalışmada, resveratrol uygulamasının hücresel GSH düzeyini kontrol gruba göre anlamlı derecede yükselttiği bildirilmiştir (Li ve ark., 2006). Verilerimiz literatürdeki bilgilere paralel olarak kadmiyumun kontrol grubuna nazaran kalp dokularında MDA, NO ve TSA düzeylerini istatistiksel olarak arttırdığını fakat GSH düzeylerini ise azalttığını göstermektedir. Kadmiyum+resveratrol verilen grupta ise kadmiyumun MDA konsantrasyonuna yapmış olduğu olumsuz etkiyi resveratrolün önlediği görülmüştür. Çünkü aynı grubun MDA konsantrasyonu için kontrole karşı yapılan karşılaştırılmasında istatistiksel bir fark çıkmamıştır. Fakat GSH, NO ve TSA konsantrasyonlarında resveratrol sayısal değer olarak kadmiyumun etkisini önlemiş gibi görünsede kontrole karşı istatistiksel olarak fark görülmektedir. Lindberg ve ark. (1991) yaptıkları bir çalışmada, serum TSA konsantrasyonları ile kardiovasküler hastalıklar nedeniyle ölümler arasında bir ilişki olduğunu bildirmişlerdir. Bu yönüyle çalışmamızda, resveratrol aracılı olarak düşen TSA seviyelerinin, pozitif kardiyovasküler etkilerinin de olduğu söylenebilir.

Sonuç olarak bu çalışmada, kadmiyum uygulanan farelerin karaciğer, böbrek ve kalp dokusunda oksida- tif stresin indüklendiğini ve antioksidan sistemin kadmiyumun toksik etkisini elimine etmede yetersiz kaldığını göstermektedir. Resveratrol ve kadmiyum+resveratrol uygulanan farelerde ise karaciğer, böbrek ve kalp dokusunda ise oksidatif stresin azaldığı ve antioksidan sistemin kadmiyumun toksik etkisini azaltarak doku hasarını önlediği kanısına varılmıştır.

\section{Teşekkür}

2016-TS-33 kodlu proje ile bu tez çalışmasının yapılmasındaki maddi katkılarından dolayı Kafkas Üniversitesi Bilimsel Araştırma Projeleri Birimi'ne teşekkür ederiz.

\section{Kaynaklar}

Atakisi E, Merhan O. Nitric oxide synthase and nitric oxide involvement in different toxicities. Saravi SSS. ed. In: Nitric Oxide Synthase-Simple Enzyme-Complex Roles. Croatia: In Tech 2017; pp. 197-214.

Bagchi D, Bagchi M, Hassoun EA, Stohs SJ. Cadmium-induced excretion of urinary lipid metabolites, DNA damage, glutathione depletion, and hepatic lipid peroxidation in Sprague-Dawley rats. Biol Trace Elem Res 1996; 52(2): 143-54.

Beutler E, Duron O, Kelly BM. Improved method for the determination of blood glutathione. J Lab Clin Med 1963; 61: 882-8.

Coyle P, Niezing G, Shelton TL, Philcox JC, Rofe AM. Tolerance to cadmium hepatotoxicity by metallothionein and zinc: In vivo and in vitro studies with MT-null mice. Toxicol 2000; 150(1-3): 53-67.

Das DK, Maulik N. Resveratrol in cardioprotection: a therapeutic promise of alternative medicine. Mol Interv 2006; 6(1): 36-47.

El-Demerdash FM, Yousef MI, Kedwany FS, Baghdadi $\mathrm{HH}$. Cadmium-induced changes in lipid peroxidation, blood hematology, biochemical parameters and semen quality of male rats: Protective role of vitamin $\mathrm{E}$ and beta-carotene. Food Chem Toxicol 2004; 42(10): 1563-71.

El-Ebiary AA, El-Ghaiesh S, Hantash E, Alomar S. Mitigation of cadmium-induced lung injury by Nigella sativa oil. Environ Sci Poll Res 2016; 23 (24): 25356-63.

Giovannini L, Migliori M, Longoni BM, Das DK, Bertelli AA, Panichi V, Filippi C, Bertelli A. Resveratrol, a polyphenol found in wine, reduces ischemia reperfusion injury in rat kidneys. J Cardiovasc Pharmacol 2001; 37(3): 262-70.

Gross SS, Wolin MS. Nitric oxide: Pathophysiological mechanisms. Annu Rev Physiol 1995; 57: 737-69. 
Kim BM, Lee SY, Jeong IH. Influence of squid liver powder on accumulation of cadmium in serum, kidney and liver of mice. Prev Nutr Food Sci 2013; 18(1): 1-10.

Kishimoto T, Oguri T, Ohno M, Matsubara K, Yamamoto K, Tada M. Effect of cadmium $\left(\mathrm{CdCl}_{2}\right)$ on cell proliferation and production EDRF (endothelium-derived relaxing factor) by cultured human umbilical arterial endothelial cells. Arch Toxicol 1994; 68(9): 555-9.

Koyu A, Gökçimen A, Özgüner F, Bayram DS, Kocak A. Evaluation of the effects of cadmium on rat liver. Mol Cell Biochem 2006; 284(1-2): 81-5.

Li Y, Cao Z, Zhu H. Upregulation of endogenous antioxidants and phase 2 enzymes by the red wine polyphenol, resveratrol in cultured aortic smooth muscle cells leads to cytoprotection against oxidative and electrophilic stres. Pharmacol Res 2006; 53(1): 6-15.

Lindberg G, Eklund GA, Gullberg B, Rastam L. Serum sialic acid concentration and cardiovascular mortality. BMJ 1991; 302(6769): 143-6.

Merhan O, Özcan A. Kazlarda serum seruloplazmin ve total sialik asit düzeylerinin araştırılması. Kafkas Univ Vet Fak Derg 2004; 10(2): 139-42.

Miranda KM, Espey MG, Wink DA. A rapid, simple spectrophotometric method for simultaneous detection of nitrate and nitrite. Nitric Oxide 2001; 5 (1): 62-71.

Pratt DS, Kaplan MM. Evaluation of abnormal liver enzyme results in asymptomatic patients. $\mathrm{N}$ Engl J Med 2000; 342(17): 1266-71.

Renugadevi J, Prabu SM. Naringenin protects against cadmium-induced oxidative renal dysfunction in rats. Toxicology 2009; 256(1-2): 128-34.

Sarkar S, Yadav P, Trivedi R, Bansal AK, Bhatnagar D. Cadmium-induced lipid peroxidation and the status of the antioxidant system in rat tissues. J Trace Elem Med Biol 1995; 9(3): 144-9.

Sener G, Toklu HZ, Sehirli AÖ, Velioglu-Ögünç A, Çetinel S, Gedik N. Protective effects of resveratrol against acetaminophen-induced toxicity in mice. Hepatol Res 2006; 35(1): 62-8.

Shiraishi N, Rehm S, Waalkes MP. Effect of chlorpromazine pretreatment on cadmium toxicity in the male wistar (WF/NCr) rat. J Toxicol Environ Health 1994; 42(2): 193-208.

Skoczynska A, Martynowicz $H$. The impact of subchronic cadmium poisoning on the vascular effect of nitric oxide in rats. Hum Exp Toxicol 2005; 24(7):
353-61.

Skowerski M, Jasik K, Konecki J. Effects of interaction between cadmium and selenium on heart metabolism in mice: the study of $m$ RNA, protein, ANP synthesis activities and ultrastructure in mouse heart. Med Sci Monit 2000; 6(2): 258-65.

Sydow G. A simplifield quick method for determination of sialic acid in serum. Biomed Biochim Acta 1985; 44(11-12): 1721-3.

Tomera JF, Kukulka SP, Lilford K, Harakal C. Cadmium accumulation in experimental hypertension. Corn Art Dis 1991; 2: 769-74.

Tsuruoka S, Sugimoto KI, Muto S, Nomiyama K, Fujimura A, Imai M. Acut effect of cadmiummetallothionein on glucose and amino acid transport across the apical membrane of the rabbit proximal tubule perfused in vitro. J Pharmacol Exp Ther 2000; 292(2): 769-77.

Vorobieva RS, Eremeeva EP. Cardiovascular fuction in workers exposed to cadmium. Gig Sanit 1980; 10: $22-5$

Wang B, Du Y. Cadmium and its neurotoxic effects. Oxid Med Cell Longev 2013; 2013: 1-12.

Yoshioka T, Kawada K, Shimada T, Mori M. Lipid peroxidation in maternal and cord blood and protective mechanism against activated-oxygen toxicity in the blood. Am J Obstet Gynecol 1979; 135(3): 372-6.

Yousef M, Vlachogiannis IA, Tsiani E. Effects of resveratrol against lung cancer: In vitro an in vivo studies. Nutrients 2017; 9(11): 1-14. 